\title{
EL GÉNERO FANTASMA: LA TRADUCCIÓN DE SUBTÍTULOS ${ }^{1}$
}

\author{
Isabel García Adánez \\ Universidad de Alcalá
}

\begin{abstract}
This article presents some personal conclusions about the main problems of translating subtitles, which are due to the paradoxical nature of this kind of text, called here "a phantom text". Subtitles are, in fact, a written text that, on the other hand, corresponds to an oral discourse and does not fulfil any of the usual functions of a written text. This more theoretical part is followed by an exposition of the explicit and implicit rules for subtitling and a comment on the relationship between some rules and the particular type of text they refer to.
\end{abstract}

\section{REFLEXIONES SOBRE LA NATURALEZA DEL GÉNERO}

Según el Diccionario de uso del español de María Moliner, un fantasma es aquel "ser no real que alguien cree ver, soñando o despierto", una especie de ilusión pero sin verdadera entidad. En cierto modo, los subtítulos son un texto fantasma: un texto escrito, al fin y al cabo, que recoge o traduce a otro idioma cuanto se dice en una película, pero que no cumple prácticamente ninguna de las características y funciones de los textos escritos. Se trata de un texto que los espectadores leen sin ninguna conciencia de estar leyendo algo pues sólo son conscientes de estar viendo una película-, y que aspira a pasar desapercibido en todo momento. No obstante, no deja de estar fijado por escrito y, a diferencia del habla, tiene que cumplir todas las normas gramaticales que impone la escritura. Esto se debe también a que, si la principal función del subtítulo es pasar desapercibido, cualquier incorrección gramatical o cualquier giro que ofrezca dificultades para ser leído con fluidez entorpecerá la lectura y llamará la atención sobre la realidad de que hay "algo escrito" al pie de las imágenes.

Vemos pues que la propia naturaleza de los subtítulos, ya sean en el mismo idioma del original o en otro ${ }^{2}$; ya sean de largometrajes de ficción, de series televisivas o de

\footnotetext{
${ }^{1}$ Me gustaría agradecer expresamente a los estudios de subtitulación LASERFILM de Madrid su amabilidad y disposición a proporcionarme material original para analizar. Todos los fragmentos de tablas de subtítulos son originales de scripts de largometrajes subtitulados allí. También he de agradecer a Ivars Barzdevics numerosos detalles sobre la práctica de la subtitulación en otros estudios distintos de éste. Cuando no se indica la procedencia exacta de los ejemplos de texto, se trata de casos inventados con el único fin de explicar ciertas normas.

${ }^{2}$ Nos basaremos en los subtítulos que traducen la versión original de la pantalla, si bien las conclusiones serían igualmente válidas en el caso de la subtitulación para personas con problemas de audición, puesto que el peculiar choque entre lo escrito y lo oral se produce de igual manera. En el segundo tipo de subtitulación, por otra parte, habría que tener en cuenta otros factores en los que no vamos a profundizar (por ejemplo, en la audioversión se recogen también los ruidos: "se oye una sirena", "risas", "gritando"; en cambio, muchas veces, los espectadores con problemas de audición son perfectamente capaces de leer los labios de los personajes y pueden pasar por alto el texto del subtítulo, etc.).
} 
documentales, encierra una paradoja, y pensamos que es este extraño desajuste entre lo oral y lo escrito lo que constituye la mayor dificultad a la hora de traducir; no tanto el hecho de que, por problemas de espacio en la pantalla, el texto del subtítulo omita información y sea un resumen de lo que han dicho los personajes. Por extendida que esté la idea "claro, el subtítulo es más corto, por eso en el cine los nativos se ríen de los chistes y los que desconocen el idioma se quedan a medias", no es cierta en absoluto. Dicho de otra manera, los problemas o los fallos de traducción no derivan de la necesidad de encontrar formulaciones más breves (a veces) o de eliminar algún elemento de la frase hablada (el ejemplo está en que se puede cometer un error garrafal y echar por tierra una escena entera con una única palabra), sino que muchas veces son fruto de la dificultad para conciliar el discurso oral de la pantalla con una correspondencia escrita que recoja bien ciertos elementos como el tono (irónico, lírico, etc.) o el registro (coloquial, elevado, neutro). Esto es un problema de traducción básico que se da en todos los tipos de subtitulación, aunque de un modo más patente en el cine, por ser también el género con el lenguaje más creativo y complejo.

En el habla se repiten muchos elementos, es redundante por naturaleza, pues como no está fijada, requiere la reiteración de informaciones; además, está sembrada de interjecciones, de imperfecciones, de anacolutos, de vacilaciones que llenan espacio pero no significan nada, a menudo acompañadas de gestos y elementos del lenguaje no verbal. Es evidente que esto no se puede recoger por escrito, pero ya lo estamos viendo en la pantalla, conozcamos o desconozcamos por completo el idioma original de la película. No es necesario, entonces, que el texto del subtítulo recoja lo que ya nos llega por otros canales. Y aquí no hay que olvidar que el cine tiene su propio lenguaje y que los guiones han de cumplir ciertas normas de puro sentido común. No vamos a detenernos en ello, pero cabe admitir que, si un diálogo parece "recién sacado de un libro" o repite lo mismo que ya nos "dicen" las imágenes, es que el guión es malo ${ }^{3}$. Lo interesante del lenguaje hablado de la pantalla es, precisamente, lo que aporta de nuevo a la imagen. Esto será, pues, lo que el texto escrito del subtítulo debe transmitir a quienes no lo han entendido, y no cabe duda de que el abanico para reproducir numerosas variedades de registro, ironía, lirismo, coloquialismos, juegos de palabras, etc. es muy grande, y de que, en consecuencia, la calidad de esa traducción puede ser tan alta (o tan desastrosa) como en cualquier otro género. Pero, insistimos, no es cuestión de "brevedad obligada".

\footnotetext{
Un caso aparte serían los sobretítulos que cada vez se utilizan con más frecuencia en la ópera, en los cuales el texto escrito contrasta con el texto cantado, que ya de por sí es bastante peculiar y distinto del habla natural: a menudo está basado en textos literarios, otras veces en forma de diálogos, monólogos o exclamaciones, etc. Por otra parte, el problema del tiempo y la necesidad de leer deprisa, porque las imágenes pasan, resulta bastante ajeno a la ópera, puesto que el canto suele dilatar el texto hasta el punto de que sucede lo contrario: sobre un mismo sobretítulo se puede estar cantando media hora, basta con pensar en algunas arias muy adornadas que persiguen más el lucimiento técnico del cantante que la transmisión del contenido de un texto. Dejando al margen la cuestión de la música y la palabra en la ópera, que requeriría un comentario infinitamente más amplio, cabe subrayar que en la traducción de sobretítulos de ópera, además, suele ser preciso "modernizar" el texto original, algo ciertamente extraño en el cine o la televisión. Pero eso sería un tema para otro artículo.
}

\footnotetext{
${ }^{3}$ Sobre las características básicas de un buen guión y su elaboración posterior pueden consultarse, entre otras muchas, las obras de Michel Chion o de Guy Gauthier citadas en la bibliografía.
} 
Según los criterios de los estudios de subtitulación actuales, que obedecen a la psicología de los espectadores, el subtítulo ha de recoger el discurso de los personajes en tanto sonido. Dicho de otra manera: donde hay sonido -que no ruido: gemidos, suspiros, interjecciones breves, etc.-, tiene que haber un subtítulo porque los espectadores lo identifican con "se ha dicho algo" y quieren saber qué es. Hace unos veinte años, no se subtitulaban ni canciones, ni peleas, ni voces de fondo (p. ej., una radio o televisión que se oye en la pantalla, etc.), pero como nuestra sociedad globalizada se caracteriza por la desconfianza, aunque resulte fácil deducir qué se dicen dos gángsters en pleno tiroteo, qué braman los valientes soldados en la batalla contra los Orcos o qué epítetos se dedican los protagonistas de una escena de sexo duro (y, si cabe, es indiferente en todos los casos), la norma es añadir el texto para que ningún espectador rebulla intranquilo en la butaca: "no vaya a ser que estén diciendo otra cosa". Como anécdota que, sin embargo ilustra el choque entre lo oral y lo escrito que hemos expuesto, podemos subrayar que, en los subtítulos (al margen del bochorno del traductor) se ven escritas expresiones que no están concebidas para tal fin; y, además, escritas correctamente, a pesar de que no se profieren con pronunciación perfecta, todas sus consonantes bien articuladas y un hermoso signo de admiración al final. Curiosamente, al margen de la corrección política, en este tipo de traducción se permiten toda suerte de giros coloquiales y vulgares siempre que estén bien escritos y no planteen dificultades de lectura; de hecho, se exige la correspondencia con el registro de lenguaje de la pantalia, sea el que sea, del mismo modo en que se exige la corrección gramatical ${ }^{4}$. En los estudios teóricos se recomienda evitar expresiones malsonantes, etc., pero en la práctica se hace lo contrario en aras de la credibilidad de las imágenes. Resulta mucho más demoledor para una película cambiar el registro lingüístico que escribir la grosería que todo el mundo "ve decir" en pantalla. (¿Tendrían alguna credibilidad los personajes de Pulp Fiction de Tarantino si exclamaran cosas como: "iQué contrariedad! ¡Eso ha estado muy feo! Voy a agredirte...” ¿Quién no se echaría a reír?).

No hay ningún texto escrito similar al que constituye el total de subtítulos de una película. Considerando que se trata de un texto escrito que recoge un discurso hablado, cabría pensar que guarda cierta relación con las transcripciones que se realizan, por ejemplo, en los juicios o en una conferencia. Sin embargo, la función de estos textos es fijar lo que de otra manera sería efímero con la intención de analizarlo después en calidad de documento escrito. Nada más distinto de los subtítulos, que a nadie le interesan fuera del contexto del instante en que aparecen en pantalla. Por otro lado, las transcripciones se esmeran en recoger muy bien todos los detalles (con titubeos, incorrecciones, incoherencias, etc.) porque son textos concebidos expresamente para dicho análisis posterior, en el que cada detalle podrá ser examinado con todo el tiempo necesario y tendrá su importancia pragmática dentro del contexto. La relación entre el texto y el tiempo de lectura y análisis en el caso de los subtítulos es justo la contraria. De hecho, si algún detalle sugiriese en el espectador la necesidad de detenerse a analizar el texto, se perdería los siguientes subtítulos y las siguientes escenas.

Asimismo, parece evidente que ha de existir cierta semejanza con el guión de la película, pero también aquí se dan diferencias de base. Tal vez las palabras puestas por

\footnotetext{
${ }^{4}$ Véase, para más detalles, el capítulo 6 de la obra citada de F. Chaume (2004).
} 
escrito en uno y otro caso sean equivalentes (con ausencia de acotaciones escénicas en la traducción), si bien no lo son en absoluto las funciones de cada uno de los textos. El guión es el punto de partida de la película entera, la fuente de inspiración que dará lugar a imágenes, montaje, música, etc. La traducción en forma de subtítulos surge a posteriori, pero con la película ya terminada y no influye en ella en absoluto, sólo es una mera glosa al discurso hablado y sólo al discurso hablado, puesto que lo que dicen las imágenes ya ha salido a la luz en un lenguaje propio. Ahora bien, esas imágenes sí han precisado un guión previo para inspirarlas, mientras que a menudo se podría prescindir del subtítulo. El guión, en tanto que texto, tiene entidad propia, es interesante de por sí antes de convertirse película (o no se llega a rodar), y lo sigue siendo después como parte de ella, una vez rodada. Hay editoriales especializadas que publican guiones, ¿se han visto alguna vez publicados los subtítulos de una película? Además, esta traducción en realidad nunca se ve como texto entero, sino sólo de subtítulo en subtítulo. Nunca constituye un "discurso" entero.

¿Cómo puede llamarse a un texto escrito que transcurre en el tiempo? El texto de los subtítulos es un texto fantasma porque carece de entidad como texto completo y sólo existe de forma virtual, en forma de archivo en el ordenador del traductor (si lo conserva). No tiene ninguna pretensión de permanecer ni de fijar nada, sino que es la pura encarnación de lo efímero. Pasa y se pierde, como el habla (como la música y las imágenes), pero esto no es lo propio de la "literatura" o la "letra". Por otro lado, está escrito y debe ser correcto como la literatura y la letra. Con la característica añadida y un tanto paradójica de que debe ser susceptible de ser leído con gran rapidez y sin vacilar una sola vez sobre su contenido. Dicha una frase y vista una imagen, pasaron a la historia; leído un subtítulo, aparece el siguiente... ¿Y dónde está el texto? ¿Quién creyó ver un texto?

\section{NORMAS A SEGUIR EN LA TRADUCCIÓN DE SUBTÍTULOS}

Del ordenador del traductor a la gran pantalla hay un trecho, si bien la cadena puede presentar algunas variantes. Los principales eslabones que la constituyen son: la productora o distribuidora de la obra, el estudio de subtitulación y el traductor. La productora o distribuidora proporciona al estudio de subtitulación el material original para traducir (scripto guión escrito y vídeo o DVD con la filmación en el idioma original y, por lo general, con un contador numérico). A su vez, el estudio encarga la traducción y adaptación, de acuerdo con una serie de normas, a un traductor, quien después le envía el texto (en formato de texto, precisamente) para que, de nuevo en el estudio, se sincronice la aparición de los subtítulos con los fotogramas mediante el programa informático adecuado (a este proceso se le denomina "localizar" y aquí no vamos a profundizar en los distintos tipos de programas). Traducir y localizar (insertar el texto en las imágenes, sincronizar el subtítulo y los fotogramas) son dos tareas diferentes que se realizan por separado, y es importante tener en cuenta que el traductor no suele realizar este trabajo técnico. Dado el caso, puede recibir la formación necesaria y encargarse de ambas cosas, pero la formación como traductor siempre será independiente de la formación como técnico de imagen y sonido y del aprendizaje de los programas informáticos correspondientes.

Como dato, cabe señalar que son las distribuidoras y productoras las que se encargan siempre de "traducir" o asignar los títulos a las correspondientes obras, atendiendo a 
cuestiones legales como patentes, derechos adquiridos para determinadas expresiones, existencia de otras producciones con títulos similares, o simples cuestiones de marketing. (Si, por poner un ejemplo, A Foreign Affaire de Billy Wilder (1948) se titula en castellano Berlín-Occidente y en alemán Eine Auswärtige Affäre, no se debe a ningún despiste de los respectivos traductores, a quienes se suele culpar de todo detalle chocante.)

Según las posibilidades de la productora y el tipo de obra en cuestión (un largometraje, una serie de televisión de muchos capítulos, un documental, un making-off para ediciones de películas en DVD, etc.) existen distintas maneras de trabajar: por ejemplo, las grandes productoras y distribuidoras norteamericanas cuentan con estudios de subtitulación y doblaje propios, con centenares de traductores que residen en distintos países, etc., pero también existen distribuidoras independientes que requieren de intermediarios como distribuidoras en los países donde se van a proyectar sus producciones, estudios locales, etc. El proceso será algo distinto si el traductor está en contacto con el estudio de subtitulación y puede acudir a ver determinadas escenas, corregir desajustes y comentar su trabajo con el técnico (esto es lo más frecuente en la traducción de cine en España y recibe el extraño nombre de "visionar"), a si colabora con una empresa en la que varios traductores, que no se ven nunca y no tienen ningún contacto con los técnicos, se ocupan simultáneamente de una misma serie (por citar algunas de actualidad, pensemos en producciones como El Ala Oeste de la Casa Blanca, A dos metros bajo tierra, Urgencias, etc.). En cualquier caso, cada estudio proporciona al traductor su propio protocolo, más o menos rígido, según las posibilidades que hemos visto, del mismo modo en que se ofrecen unas "normas de publicación" en los congresos. Las siguientes normas son, por lo tanto, una abstracción de varios protocolos.

A grandes rasgos, existen dos formas de realizar la subtitulación, aunque los resultados son prácticamente los mismos y el espectador no percibe diferencia alguna:

a) Las normas indican un número máximo de caracteres por subtítulo, que oscila entre 37 y 40 por línea (con espacios), teniendo en cuenta que cada subtítulo puede tener dos líneas. Evidentemente, el hecho de que haya espacio (o tiempo) para un subtítulo de dos líneas no implica que haya que ocuparlo todo. Siempre hay que ser coherente con lo que se oye, aunque el espectador desconozca el idioma: no puede traducirse toda una perorata con un monosílabo, como tampoco resulta verosímil que una palabra monosílaba dicha en la pantalla corresponda a un subtítulo de dos líneas. (A diferencia de lo que sucede en la ópera, los técnicos también han de evitar que, si sobra mucho tiempo, el público se quede leyendo el mismo subtítulo varias veces. Por ejemplo, si en la pantalla se dice una sola palabra seguida de un largo silencio, una vez se ha dicho la palabra, el subtítulo desaparece, aunque se mantenga la imagen. Es de suponer que el traductor ha encontrado un equivalente escrito breve, y el técnico, a su vez, acorta el tiempo de localización hasta que aparezca siguiente subtítulo.)

b) Se indica al traductor el número exacto de caracteres por subtítulo, habiendo medido de antemano (en el estudio y gracias a los contadores insertos en la pantalla) la duración exacta del "sonido" o del "momento sonoro" (el máximo absoluto de caracteres sigue siendo el mismo -entre 37 y 40 por línea, dos líneas por subtítulo-). Esta es la práctica más habitual cuando se va a utilizar el mismo texto para la adaptación al doblaje, donde la traducción sí está muy constreñida por la articulación y por la duración real del sonido articulado en boca 
de los personajes. Sólo es posible si se entrega al traductor una tabla de subtítulos (como veremos más adelante), y también el programa informático que se utiliza después para la sincronización con los fotogramas es algo diferente.

\subsection{Tablas y listas de subtítulos}

\subsubsection{Tablas de subtítulos.}

Hablamos de tabla de subtítulos cuando recibimos el texto (script) ya dividido en subtítulos y sólo hay que traducirlo respetando esta división (y, por supuesto, los principios de coherencia con la imagen, etc. que ya hemos expuesto). La labor de adaptación a la imagen viene realizada de antemano por los técnicos del estudio, y ésta es la práctica habitual en la mayoría de productoras cinematográficas de cierto peso, sobre todo las norteamericanas. Por lo general, en estos estudios del país de origen, realizan también los subtítulos para espectadores con problemas de audición, que equivaldría a una adaptación del lenguaje cinematográfico al lenguaje escrito (fantasma) sin necesidad de traducir nada.

El subtitulado en otro idioma que adopta los códigos de localización que ya figuran en una tabla se denomina simplemente "traducción". A su vez, las tablas pueden presentar varios formatos e incluso anotaciones para facilitar la traducción.

Ejemplos:

a) Fragmento del script original de Lord of the Ringsde Peter Jackson (El Señor de los Anillos, 2001): tabla con indicador del número de caracteres por subtítulo para el traductor.

\begin{tabular}{|l|l|l|}
\hline [The world is changed.] & $1,45 \mathrm{c}$. & \\
\hline [I feel it in the water.] & $2,46 \mathrm{c}$. & \\
\hline [I feel it in the earth.] & $3,44 \mathrm{c}$. & \\
\hline [I smell it in the air.] & $4,45 \mathrm{c}$. & \\
\hline [Much that once was...] & $5,29 \mathrm{c}$. & \\
\hline [...is lost.] & $6,23 \mathrm{c}$. & \\
\hline [For none now live who remember it.] & $7,46 \mathrm{c}$. & \\
\hline $\begin{array}{l}\text { [It began with the forging] } \\
\text { [of the Great Rings.] }\end{array}$ & $8,66 \mathrm{c}$. & \\
\hline [Three were given to the Elves:] & $9,28 \mathrm{c}$. & \\
\hline $\begin{array}{l}\text { [Immortal, wisest and fairest] } \\
\text { [of all beings.] }\end{array}$ & $10,57 \mathrm{c}$. & \\
\hline [Seven to the Dwarf-lords:] & $11,31 \mathrm{c}$. & \\
\hline $\begin{array}{l}\text { [Great miners and craftsmen] } \\
\text { [of the mountain halls.] }\end{array}$ & $12,66 \mathrm{c}$. & \\
\hline [And nine...] & $13,19 \mathrm{c}$. & \\
\hline $\begin{array}{l}\text { [...nine rings were gifted] } \\
\text { [to the race of Men...] }\end{array}$ & $14,45 \mathrm{c}$. & \\
\hline [...who, above all else, desire power.] & $15,58 \mathrm{c}$. & \\
\hline
\end{tabular}


b) Fragmento del script original de Charlie and the Chocolate Factory de Tim Burton (2005): tabla con códigos de localización para los técnicos y anotaciones para el traductor. El texto para traducir aparece en negrita (la negrita es mía).

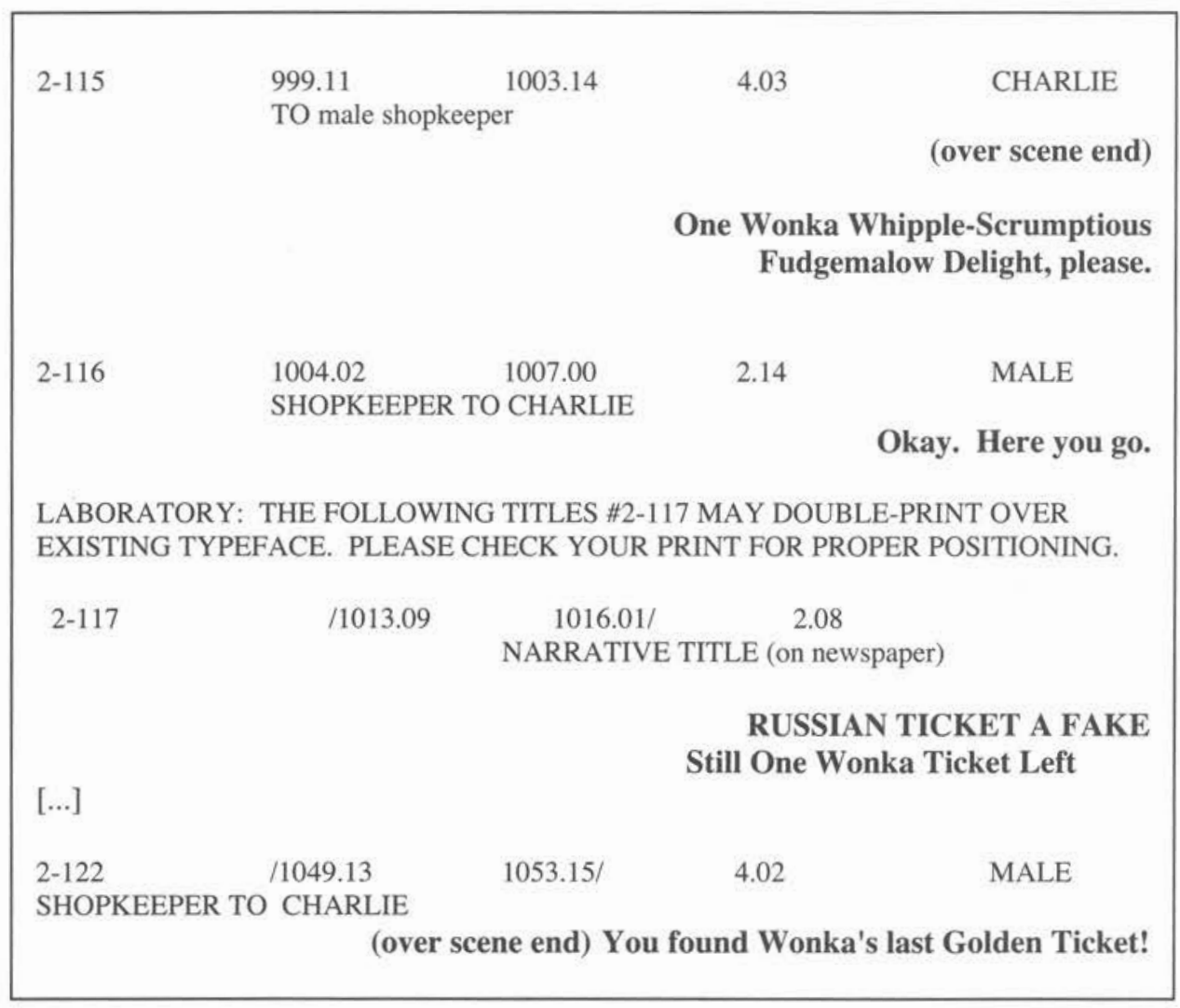


c) Fragmento del script original de The Curse of the Jade Scorpion de Woody Allen (La maldición del escorpión de Jade, 2002): tabla con los códigos de localización para el técnico.

00:24:33:18, 00:24:36:06, What are you doing I in my mother's closet?

00:24:37:08, 00:24:39:00, Well, hello.

00:24:40:17, 00:24:44:09, You're one of those grubby I private detectives, aren't you?

00:24:44:19, 00:24:49:08, A private eye, they're called. I A shamus. A gumshoe.

$00: 24: 49: 16,00: 24: 52: 17$, No, I'm a grubby I insurance investigator.

00:24:53:01, 00:24:56:04, Private eyes are romantic. I I'm just grubby.

00:24:56:11, 00:24:59:05, You always get your kicks I fondling women's shoes?

00:24:59:12, 00:25:02:11, No, once in a while I'll fondle I a whole woman.

00:25:02:17, 00:25:05:01, You have a fresh mouth. I I'm not sure I like you.

00:25:05:07, 00:25:09:19, I grow on people. We could meet I later, and I could grow on you.

00:25:09:24, 00:25:12:18, You don't seem tough enough | to go after criminals.

00:25:12:24, 00:25:15:15, Maybe if I slap you around, I you'll change your mind.

$00: 25: 15: 22,00: 25: 17: 05$, I could slap you back.

$00: 25: 17: 10,00: 25: 20: 08$, This is starting to sound like fun. I Shall we put some music on?

\subsubsection{Listas de subtítulos}

Una lista de subtítulos es el resultado de la adaptación de un script que no está subdividido en modo alguno, sino que presenta la forma similar a la de un guión o una obra de teatro. En este caso, es el traductor quien se encarga de "cortar" el texto para transformarlo en subtítulos, que después el técnico verificará y hará encajar en los fotogramas mediante el programa informático adecuado. No sólo se trata pues de traducir, sino de calcular, siguiendo el ritmo de las imágenes y los criterios habituales sobre el número de caracteres posibles, en qué bloques de texto se dividirá el discurso. Para ello, el traductor se rige por la cadencia de las frases del habla, los silencios, etc., así como por los cambios de plano de la imagen. Es una labor que requiere cierto entrenamiento, distinto de las técnicas de traducción, pero que no presenta excesivas dificultades una vez se conoce el lenguaje cinematográfico. No hay que olvidar que tampoco el lenguaje de un guión especialmente denso ni en su contenido ni en su formulación y, cuando hay una voz de un narrador, suele declamar en un tono pausado para que pueda captarse bien toda la información. De hecho, los técnicos que realizan las tablas de subtítulos a menudo desconocen los idiomas originales (o no están pendientes de la traducción en absoluto) y se 
orientan perfectamente en función del sonido, como si se tratase de una partitura, y de la imagen.

Este trabajo de subtitulado se denomina "traducción y adaptación" y, también a efectos retributivos, se considera diferente a la mera traducción. Es lo habitual en cine europeo, cine independiente en general, $y$ en numerosos documentales.

Por último, puede darse el caso de que no exista texto de apoyo alguno y que el traductor-adaptador deba extraer todo el discurso de oído. No es necesario que proporcione al estudio el texto en idioma original, sino directamente una lista de subtítulos. No es lo más frecuente, pero se dan casos, sobre todo en documentales con entrevistas breves y en películas reconstruidas con escenas añadidas, etc.

Ejemplo: fragmento del guión original de Goodbye Lenin! de Wolfgang Becker (2003). Con indicaciones de las voces en off, de los enclaves de cada escena y del personaje que habla en cada momento.

a) Versión original:

\section{MUTTER}

Was, der Jähn?

\section{DENIS (TV)}

Sigmund Jähn war 1978 als erster Deutscher im All.

Das neue Staatsoberhaupt wandte sich noch am Abend an die Bevölkerung der Deutschen Demokratischen Republik.

\section{"SIGMUND JÄHN"}

Liebe Bürgerinnen, liebe Bürger der Deutschen Demokratischen Republik. Wenn man einmal das Wunder erlebt hat, unseren blauen Planeten aus der Ferne des Kosmos zu betrachten, sieht man die Dinge anders. Dort oben in den Weiten des Weltalls, kommt einem das Leben der Menschen klein und unbedeutend vor. Man fragt sich, was die Menschheit erreicht hat, welche Ziele hat sie sich gestellt und welche hat sie verwirklicht. Unser Land hat heute Geburtstag. Aus dem Kosmos gesehen ist es ein sehr kleines Land und doch sind im letzten Jahr Tausende Menschen zu uns gekommen. Menschen, die wir früher als Feinde gesehen haben und die heute hier mit uns leben wollen. Wir wissen, dass unser Land nicht perfekt ist. Aber das, woran wir glauben, begeisterte immer wieder viele Menschen aus aller Welt. Vielleicht haben wir unsere Ziele manchmal aus den Augen verloren, doch wir haben uns besonnen. Sozialismus, das heißt, sich nicht einzumauern. Sozialismus, das heißt auf den anderen zugehen, mit dem anderen zu leben. Nicht nur von einer besseren Welt zu träumen, sondern sie wahr zu machen. Ich habe mich daher dazu entschlossen, die Grenzen der DDR zu öffnen. 
b) Lista de subtítulos correspondiente

(Traducción y adaptación para salas de cine y DVD: LASERFILM/I. García Adánez)

¿Jähn?

[Sigmund Jähn fue, en 1978]

[el primer cosmonauta alemán.]

[El nuevo jefe de estado]

[se ha dirigido]

[esta misma noche]

[al pueblo de la RDA.]

Queridos ciudadanos de la RDA.

Cuando uno ha vivido el milagro

de ver nuestro planeta azul

desde la lejanía del cosmos,

Se ven las cosas de otra manera.

Allí arriba,

en la inmensidad del espacio,

La vida de los hombres

parece pequeña e insignificante.

Uno se pregunta:

¿Qué ha conseguido el hombre?

¿Qué metas se ha puesto, y cuáles ha alcanzado?

Nuestro país cumple años hoy.

Visto desde el espacio,

es un país muy pequeño.

Sin embargo, ahora han venido

a él miles de personas.

Personas que antes

considerábamos enemigos, 
y que ahora

quieren vivir con nosotros.

Sabemos que nuestro país

no es perfecto.

Pero aquello

en lo que creemos

no ha dejado de entusiasmar

a mucha gente de todo el mundo.

Posiblemente hayamos

perdido de vista nuestras metas.

Pero hemos recapacitado.

El socialismo no es sinónimo

de construir muros.

El socialismo significa

acercarse a los demás,

vivir con los demás.

No sólo soñar con un mundo mejor, sino hacerlo realidad.

He decidido abrir

las fronteras de la RDA.

\subsection{Espacios y marcas tipográficas}

\subsubsection{Separación entre líneas y entre subtítulos}

A la hora de dividir un subtítulo en dos líneas no se deben interrumpir sintagmas, es decir, no separar el artículo del sustantivo ni la preposición del complemento preposicional o del verbo que forma la perífrasis, etc.

Ejemplos:

Me voy/ a mi casa / a dormir/ la siesta.

*Incorrecto:

* Me voy al mi casa a dormir la siesta (separa el sintagma preposicional)

* Me voy a mil casa a dormir la siesta (separa el posesivo del sustantivo) 
* Me voy a mi casa al dormir la siesta (separa la preposición del verbo)

Del mismo modo, en el caso de que una frase abarque varios subtítulos, se intentará no interrumpir proposiciones, salvo que sea intencionado por parte del director, buscando la sorpresa. En las frases interrumpidas pueden usarse puntos suspensivos para indicar que continúa, pero no son necesarios si resulta clara la división de las proposiciones.

Ejemplo (primera frase de Inteligencia Artificial de S. Spielberg):

Corrían los tiempos

que siguieron al deshielo,

provocado por

el efecto invernadero.

*Incorrecto:

Corrían los tiempos que siguieron al...

*deshielo, provocado por

el efecto invernadero.

A continuación veremos los distintos tipos de letra y marcas tipográficas que son utilizados únicamente de la siguiente manera.

\subsubsection{Cursiva}

a) para la voz en off (que, a su vez, puede ser de un narrador o de algún personaje que queda fuera de plano, de manera que la fuente del sonido está fuera de lo que se ve en pantalla y no se puede deducir de las imágenes). El estudio indica cómo señalizar la cursiva, pero lo más frecuente es entre corchetes [ ] o con \#, que el programa reconoce automáticamente como funciones. No se utilizan la cursiva ni el subrayado como en los textos escritos normales.

Ejemplo:

El traductor señala: o

[Corrían los tiempos] \#Corrían los tiempos

[que siguieron al deshielo] \# que siguieron al deshielo

En la pantalla se leerá:

Corrían los tiempos

que siguieron al deshielo,

Cuando el subtítulo tiene dos líneas, se deben marcan las dos; si la voz en off comienza en mitad de un subtítulo o, por el contrario, una frase comience en off y, con un cambio de plano, aparece la fuente de sonido en pantalla, se marca en cursiva el fragmento correspondiente. 
b) Para palabras extranjeras que deben permanecer así:

Marcamos:

Ayer comimos un [bretzel] muy rico.

En la pantalla se leerá:

Ayer comimos un bretzel muy rico.

\subsubsection{Guiones de diálogo}

Se emplean cuando hablan dos personajes dentro de un mismo subtítulo.

$-¿$ Qué dices que comiste?

-Un \#bretzel\#, típico de Alemania.

\subsubsection{Comillas}

Aparecen de manera excepcional, para señalizar citas de cualquier tipo (ejemplo 1) y las escasas incorrecciones lingüísticas o juegos de palabras que, por exigencias del guión, se deban mantener en el texto (ejemplo 2).

Ejemplo 1:

Ayer vi "Casablanca" y lloré a mares.

Ejemplo 2:

Es tan vulgar que dice

"me se ha caído".

\subsubsection{Mayúsculas}

De uso exclusivo para los títulos (de la propia película al comenzar o terminar) y para los rótulos que puedan aparecer en pantalla -títulos de libros que se ven de manera patente, carteles, anuncios, etc.) Este es el único caso en que el subtítulo no recoge el habla o el sonido de la pantalla, sino otro texto inserto en las imágenes (el caso excepcional dentro del lenguaje de la imagen, donde justamente no se "lee" nada escrito).

Ejemplo 1 (inventado): una pareja se abraza delante de un cine. No hay ningún sonido, no hablan y se ve el cartel de la película donde se lee claramente el título "Wings of Desire" (película de Wim Wenders, 1974) traducida, como rótulo, por el título en castellano:

\section{CIELO SOBRE BERLÍN}

Ejemplo 2 (de Cielo sobre Berlín): al pasar junto al "Checkpoint Charlie", los personajes se detienen un segundo a mirar el célebre cartel: 


\section{EL SECTOR AMERICANO}

\subsection{Normas tácitas}

Junto a las normas que hemos visto y que figuran en los protocolos de los estudios de subtitulación, existen una serie de normas no implícitas que el traductor va aprendiendo, por así decirlo, con la práctica, basándose en su sentido común y en las correcciones que siempre hacen las distribuidoras. A pesar de no ser filólogos, de no saber idiomas y de otras muchas carencias, siempre tienen la última palabra antes de la emisión pública de la obra. Por otra parte, es indudable que poseen un gran conocimiento de lo que hemos llamado "psicología de los espectadores" y cierto es que los criterios a la hora de decidir si una traducción es "correcta" o "adecuada" se antojan mucho más coherentes -o, cuando menos, comprensibles- si pensamos que están relacionados con el tipo de texto tan peculiar ante el que nos encontramos, con este problema de la "escritura fantasma". Así pues, también hay que tener en cuenta los siguientes aspectos:

1) Deben evitarse las secuencias que, por su forma externa, entorpezcan la lectura. Esto afecta a secuencias con más de tres monosílabos seguidos:

* Aún has de ir a por el pan.

Mejor: te falta traer el pan.

Y a las secuencias de palabras de más de tres sílabas seguidas:

*Resulta verdaderamente desagradable.

Mejor: En verdad resulta desagradable.

2) Los números se suelen poner en cifra, siempre que se facilite la lectura.

Mi teléfono es el 3556214.

El billete me ha costado $300 \$$.

Por otra parte, no suelen dejarse cifras aisladas formando un subtítulo. (Imaginemos un grupo de soldados haciendo flexiones, llevando la cuenta).

$*_{i} 1 ! ; 2$ !

Mejor: ¡Uno! ¡Dos!

3) Las interrogativas indirectas suelen convertirse en preguntas directas (y, por lo general, se omite el verbo interrogativo):

* Me pregunto quién se lo ha dicho.

Mejor: ¿Quién se lo habrá dicho?

4) Cuando hay enumeraciones o apelaciones, es preferible marcarlas con dos puntos para que sea más evidente y, si cabe, eliminar conjunciones intermedias.

*Vino toda su familia, sus padres, sus hermanos...

Mejor: vino toda su familia: padres, hermanos... 
5) Debe restringirse el uso de expresiones ambiguas o excesivamente rebuscadas, excepto exigencias del guión. Todo lo que no pueda entender el espectador medio es poco recomendable y, a veces, el criterio más filológico no es el que mejor responde a la opinión de las distribuidoras. Lejos de la manipulación del estilo de la película, en igualdad de condiciones se preferiría, por ejemplo, el cuantitativo "muy" a "harto", el adjetivo "original" a "prístino", etc.

6) Cuando una palabra o el orden de una frase resulta muy transparente al castellano (y sucede con bastante frecuencia en inglés y francés y, en general, con los latinismos de cualquier idioma), es conveniente incluirla en el subtítulo, aunque no sea la preferida por el traductor. A ser posible, en la misma posición.

Excepto en los casos de "falsos amigos" (también muy frecuentes en las traducciones del inglés), en los estudios y distribuidoras (donde no prima el criterio filológico sino el cumplir con las expectativas del público) insisten mucho en este detalle porque, en los escasos segundos que dura el subtítulo, la idea inmediata del espectador es: "si yo he entendido X (pongamos: "elfos inmortales") y ese subtítulo está mal porque dice Y (pongamos: "seres eternos")". Dentro del flujo de la película, nadie se detiene a reflexionar que podría ser un sinónimo lo que ha visto o una frase ordenada de otra manera; simplemente, no le coincide el sonido de lo poco que entiende con el texto escrito que lo representa y eso le perturba.

Ejemplo (cita libre de V.O. de La comunidad del Anillo de Peter Jackson ${ }^{5}$ ):

Three Rings were given to the Elves:

Immortal, wisest and fairest

of all beings.

Sería conveniente conservar la estructura:

\#Tres Anillos correspondieron a los Elfos:\#

\#Inmortales, los seres\#

\#más sabios y justos de todos.\#

7) Si bien, como mencionamos antes, se permiten toda suerte de manifestaciones coloquiales e incluso del lenguaje vulgar -de hecho, casi se exigen si ése es el registro que utilizan los personajes y el que concuerda con la imagen-, deben evitarse los localismos que entorpezcan la comprensión a hablantes de otras zonas o que pudieran resultar chocantes en contraste con las imágenes (¿cómo quedaría: “iVirgen de la Macarena!” en boca de Woody Allen?), así como aquellas palabras de uso común en castellano consideradas groseras en español de América.

8) Por último, está absolutamente prohibido que en los subtítulos figuren nombres de marcas registradas, puesto que podría interpretarse como publicidad escrita y requeriría el

\footnotetext{
${ }^{5}$ La negrita es mía
} 
pago de derechos a las correspondientes empresas (a cargo de la distribuidora de la película). En el discurso hablado, esto es mucho más flexible (pues la legislación no puede penalizar la "pronunciación" de nombres de marcas, una aparición efímera de nombres dentro de un discurso), pero jamás veremos en ningún subtítulo que nadie tome ese medicamento universal, compuesto de ácido acetil-salicílico, que en España se comercializa en cajitas de color verde y cuyo nombre, en teoría, tampoco podríamos escribir aquí sin pagar derechos. Dada la evidente dificultad de la lectura del medicamento genérico, los personajes aquejados de dolor de cabeza de las películas tomarán simplemente un "analgésico" o una "pastilla".

\section{CONCLUSIONES}

Son ya muchos los estudios teóricos sobre cine y traducción ${ }^{6}$; todos ellos, sin duda, mucho más ilustrativos y detallados que este breve artículo. Sin embargo, hemos querido llamar la atención sobre un aspecto muy poco mencionado hasta ahora y aportar así una pequeña novedad en el análisis de este género: el choque entre lo oral y lo escrito.

Este nuevo enfoque explicaría, por ejemplo, por qué, en la práctica, la mayoría de las normas de la traducción de subtítulos -sobre todo esas normas no explícitas- comprenden importantes concesiones en lo que sería una traducción filológica estricta en aras de otros criterios, como la psicología del espectador. ¿En qué tipo de texto escrito se considera que lo fundamental es que el ciudadano medio pueda leerlo sin tropezar y en un par de segundos? La mayor peculiaridad y dificultad práctica de este género es, pues, que, siendo un texto escrito, pretende corresponderse con algo que nunca se escribe, y que, a diferencia de todos los demás textos escritos, transcurre en el tiempo, como hacen otros lenguajes muy distintos: el habla, la música o la imagen.

El mayor problema de los subtítulos es que no son un texto (escrito), sino el fantasma de un texto, cuya principal función es "no ser visto" en toda la película. Al mismo tiempo, el público tiene que salir del cine habiendo entendido a la perfección cuanto se ha dicho en la pantalla. Así pues, como en las películas de terror, lo que menos deseamos todos es que el "fantasma" se materialice y toparnos con él de frente. Y, por desgracia, el mayor susto se lo llevará el traductor, pues aunque no presencie el instante en que los espectadores se acuerden de él cuando les perturbe el subtítulo o piensen que su traducción no es buena (o ciertamente no lo sea), sí que habrá de padecer alguna reprimenda de la distribuidora o del estudio... y el temor a que no le contraten para la siguiente película.

\footnotetext{
${ }^{6}$ Son muy recomendables las obras citadas de J. Díaz Cintas, ya un clásico, y F. Chaume.
} 


\section{REFERENCIAS BIBLIOGRÁFICAS}

AGOST, R. / CHAUME, F. (eds.), La traducción en los medios audiovisuales, Castellón de la Plana, Universitat Jaume I, 2001.

CHAUME, F., Cine y traducción, Madrid, Cátedra, 2004.

CHION, M., Cómo se escribe un guión, Madrid, Cátedra, $2004^{10}$.

CHION, M., La voz en el cine, Madrid, Cátedra, 2004.

DÍAZ CINTAS, J., La traducción audiovisual. El subtitulado, Salamanca, Almar, 2001.

DÍAZ CINTAS, J., Teoría y práctica de la subtitulación. Inglés-Español, Barcelona, Ariel, 2003.

DURO MORENO, M. (coord.), La traducción para el doblaje y la subtitulación, Madrid, Cátedra, 2001.

GAUTHIER, G., Veinte lecciones sobre la imagen y el sentido, Madrid, Cátedra, 2004². 